\title{
BMJ Open Association between self-reported length of time in the USA and blood lead levels: National Health and Nutrition Examination Survey 2013- 2016
}

Christelene Jack Horton, ${ }^{1}$ Lalatendu Acharya, ${ }^{2}$ Ellen M Wells ${ }^{\bullet}$

To cite: Horton CJ, Acharya L, Wells EM. Association between self-reported length of time in the USA and blood lead levels: National Health and Nutrition Examination Survey 2013-2016. BMJ Open 2019;9:e027628. doi:10.1136/ bmjopen-2018-027628

- Prepublication history and additional material for this paper are available online. To view these files, please visit the journal online (http://dx.doi. org/10.1136/bmjopen-2018027628).

Received 31 October 2018 Revised 20 May 2019 Accepted 18 June 2019

\section{Check for updates}

(c) Author(s) (or their employer(s)) 2019. Re-use permitted under CC BY-NC. No commercial re-use. See rights and permissions. Published by BMJ.

${ }^{1}$ School of Health Sciences, Purdue University, West Lafayette, Indiana, USA ${ }^{2}$ Allied Health Sciences, Indiana University System, Kokomo, Indiana, USA

Correspondence to Dr Ellen M Wells; wells54@purdue.edu

\section{ABSTRACT}

Objectives The aim of this study is to determine the association between length of time in the USA with blood lead (BPb).

Design Population-based cross-sectional study using data from the 2013-2016 National Health and Nutrition Examination Survey.

Setting USA.

Participants 5933 men and women ( $\geq 15$ years); subgroups of men only ( $n=2867)$, women only $(n=3064)$ and women of childbearing age $(15-45$ years) $(n=1580)$.

Primary and secondary outcomes The primary outcome was $\mathrm{BPb}$ concentration. The main exposure variable was self-reported number of years spent in the USA, categorised as: born in the USA; 0-4 years; $5-9$ years; $10-19$ years and $\geq 20$ years. We used linear regression models adjusted for race/ethnicity, education, blood cotinine, age, sex (as appropriate) and accounted for complex survey design.

Results Women of childbearing age who have lived 0-4 years in the USA have, on average, a $54 \%$ (95\% Cl $36 \%$ to $75 \%$ ) higher BPb compared with women born in the USA. Corresponding results for all women, men and the entire population were $49 \%$ (95\% Cl $34 \%$ to $66 \%), 49 \%$ (95\% Cl $28 \%$ to $75 \%$ ) and $49 \%$ (95\% Cl $33 \%$ to $66 \%)$, respectively. Similar, statistically significant, results were observed for other time periods (5-9 years, $10-19$ years and $\geq 20$ years); the magnitude of the association decreased with increasing time in the USA.

Conclusions This study provides additional evidence that newcomers to the USA may be a population at higher risk of elevated $\mathrm{BPb}$.

\section{INTRODUCTION}

Lead has a low melting point and high malleability. Due to these characteristics, lead has a long history of widespread industrial use, including as an antiknock agent in gasoline, pigment in paint and glazes, plumbing and medicines. ${ }^{1}$ It is estimated that 300 million metric tons of lead was entered into commerce in the past 5000 years. $^{2}$
Strengths and limitations of this study

- A population-representative sample of US adults and adolescents includes analyses of a subset of women of childbearing age.

- Newcomers are defined as those who reported less time spent in the USA prior to the survey; data on immigration/resident status were not available.

- Blood lead (BPb) was measured using inductively coupled plasma mass spectrometry.

- Analyses accounted for the complex sampling design, including non-response and oversampling of selected groups.

- Associations between newcomer status and $\mathrm{BPb}$ were determined using linear regression models controlling for race/ethnicity, education, blood cotinine, age and sex (as appropriate).

Lead exposure continues to be a major public health concern both globally ${ }^{3}$ and within the USA. ${ }^{4}$ Lead adversely affects every organ system in the body, inhibiting enzymatic processes and inducing oxidative stress, ${ }^{5}$ but is particularly noted for its impact as a neurotoxin. ${ }^{6}$ Even at doses below the current US Centers for Disease Control and Prevention (CDC) reference level of $5 \mu \mathrm{g} / \mathrm{dL}$, lead exposure is associated with cardiovascular effects, kidney effects, cognitive dysfunction, adverse reproductive outcomes and increased risk of hypertension and tremors. ${ }^{7}$ No safe level of lead exposure has been identified, and even a small increase in blood lead $(\mathrm{BPb})$ may have a detrimental impact. ${ }^{8}$

Studies suggest that most immigrants to the USA are healthier than natural born citizens in that they have lower rates of obesity, hypertension and chronic disease. ${ }^{9} 10$ However, they may be more likely to have elevated $\mathrm{BPb}$ concentrations. Research on children and adults who are newcomers to the USA, ${ }^{11-14}$ 
Canada, ${ }^{15-17}$ Greece $^{18}$ and Taiwan ${ }^{1920}$ consistently report that newcomers have higher $\mathrm{BPb}$ than their native counterparts. At the same time, immigration to the USA has been rapidly increasing: 59 million new immigrants have arrived in the USA in the past 50 years,${ }^{21}$ and it is anticipated that by 2060 , immigrants will make up $20 \%$ of the US population. ${ }^{22}$ Therefore, elevated $\mathrm{BPb}$ among immigrants could pose a substantial public health burden.

$\mathrm{BPb}$ concentrations represent a combination of current lead exposure as well as lead released from long-term storage sites in bone tissue into the bloodstream. ${ }^{23}$ There is substantial evidence that the rate at which lead mobilises from bone tissue during pregnancy, as calcium needs increases during pregnancy. ${ }^{24}$ More specifically, it has been estimated that $45 \%-70 \%$ of lead in blood of women of reproductive age comes from lead stored in tissues, ${ }^{25}$ and during pregnancy and lactation, $\mathrm{BPb}$ concentrations may increase by $15 \%-20 \% .{ }^{26}$ Additionally, lead can readily cross from a pregnant woman's blood to the fetus, ${ }^{27}$ which is of concern because in utero lead exposure can result in long-term, even lifetime, health impacts. ${ }^{28}$

Taken together, the evidence suggests that newcomers to the USA, particularly women of childbearing age, should be of concern for lead exposure; however, there are still relatively few studies focusing on adult men/ women immigrants or newcomers to the USA. This manuscript refers to newcomers as a broader group of immigrants, refugees and others not born in the USA. The aim of this study is to evaluate the relationship of $\mathrm{BPb}$ with self-reported length of time within the USA as an indicator of newcomer status using a large, representative population of US adults. We hypothesised that individuals not born in the USA would have higher $\mathrm{BPb}$, particularly the more recent arrivals.

\section{METHODS}

\section{Study design and population}

This cross-sectional study used data from the 2013-2016 National Health and Nutrition Examination Survey (NHANES); NHANES is designed and operated by the US CDC.

NHANES is conducted in 2-year cycles: each cycle includes a representative sample of the US population. Data from two cycles (2013-2014, 2015-2016) were included in this analysis. NHANES participants were selected using a stratified multistage probability sampling design. NHANES uses a complex sampling design, which includes sampling weight is used to produce nationally representative data. Oversampling of selected populations is conducted to increase the reliability and precision of estimates of health status indicator for these subgroups. All NHANES participants were asked to complete an in-home interview; a subset of participants also complete a physical examination and have samples collected for laboratory analysis. More details regarding the study design and protocols are available at http://www.cdc.gov/nchs/nhanes.
NHANES 2013-2016 included 20146 participants, 10175 from 2013 to 2014 and 9971 from 2015 to 2016. Inclusion criteria for this analysis were having data on $\mathrm{BPb}$, age $\geq 15$ years and data on time in the USA. A total of 7012 persons were excluded for being $<14$ years, 7110 were excluded for not having $\mathrm{BPb}$ data and 91 were excluded for not having data on self-reported time in the USA, leaving $\mathrm{n}=5933$ for analyses on adults and adolescents, of which $\mathrm{n}=2867$ were men and $\mathrm{n}=3064$ were women. Analyses were also conducted on the subgroup of women of childbearing age, $15-45$ years; $n=1580$.

\section{Study variables}

We used country of birth and self-reported length of time in the USA as indicators of newcomer status. This was the main exposure of interest and was obtained during the in-home interview. Participants were asked what country they were born in and the length of time they have been in the USA. These were combined into a single variable with five categories: (1) born in the USA, (2) living in the USA for 0-4 years, (3) living in the USA 5-9 years, (4) living in the USA for 10-19 years and (5) living in the USA for $\geq 20$ years.

Whole $\mathrm{BPb}$ concentration, measured in $\mu \mathrm{g} / \mathrm{dL}$, was the outcome of interest. A randomly selected $1 / 2$ subsample of collected blood samples were analysed for $\mathrm{BPb}$. To reduce the potential for sample contamination, collection devices and containers were prescreened for metals before use. Blood samples were transported at cold temperatures $\left(2^{\circ} \mathrm{C}-8^{\circ} \mathrm{C}\right)$ and stored at $-20^{\circ} \mathrm{C}$ or lower. Metal assays were performed by the Inorganic Radionuclides and Toxicology Division of Laboratory Sciences, National Center for Environmental Health, CDC (Atlanta, Georgia, USA) using inductively coupled plasma-dynamic reaction cellmass spectrometry. The lower limit of detection (LLOD) for $\mathrm{BPb}$ was $0.07 \mu \mathrm{g} / \mathrm{dL}$. Lead concentrations below the LLOD were replaced with LLOD divided by the square root of 2 for analyses. There were $3(0.04 \%) \mathrm{BPb}$ measurements $<$ LLOD. In 2012, the CDC reduced its action level for $\mathrm{BPb}$ to $5 \mu \mathrm{g} / \mathrm{dL},{ }^{29}$ which we use to define elevated $\mathrm{BPb}$ in our population.

Demographic and lifestyle data were obtained during the in-home interview. This included age, sex, race/ ethnicity and highest level of educational attainment. Race/ethnicity was classified as non-Hispanic (NH) white, $\mathrm{NH}$ black, NH Asian, Hispanic and other race/multiracial. Education was classified into five categories: (1) age $\leq 19$ years, (2) <high school, (3) high school degree, (4) some college and (5) $\geq 4$ year college degree. Smoking status was determined using self-reported smoking status from NHANES questionnaire data. Persons who reported smoking at least 100 cigarettes in life and that current smoking were classified as a smoker; otherwise, persons were classified as non-smokers.

\section{Statistical analyses}

Statistical analyses were performed using Stata V.13 SE for Windows. The analyses incorporated blood metal weights 
and used commands specific to analysing survey datasets. Analysing the data by taking into account the design, non-response and oversampling ensures that the results of our analyses are unbiased estimates with response and oversampling ensures that the results of our analyses are unbiased estimates with accurate statistical significance levels. A $p \leq 0.05$ was considered statistically significant.

Confounding variables were identified based on previously published evidence $\mathrm{e}^{2330}$ and initial assessment of the variables' association with length of time in the USA and $\mathrm{BPb}$. Adjusted models for women of childbearing age controlled for age (continuous), race/ethnicity (categorical), education (categorical) and serum cotinine (smoker/non-smoker). Adjusted models for all adolescents and adults $\geq 15$ years old additionally controlled for sex (male/female).

Descriptive statistics were used to present the distribution of study variables in the sample. Summary statistics were expressed as sample frequency counts as well as population-weighted percentages $(95 \% \mathrm{CI})$ for categorical variables and population-weighted mean $(95 \% \mathrm{CI})$ for continuous variables. Linear regression models were used to determine the association between length of time in the USA with $\mathrm{BPb}$. $\mathrm{BPb}$ was lognormally distributed; therefore, a natural logarithm transformation of $\mathrm{BPb}$ was used for its inclusion as a continuous variable in linear regression models and we present model coefficients $(95 \% \mathrm{CI})$ or the per cent increase in $\mathrm{BPb}(95 \% \mathrm{CI})$. Per cent increase was calculated by exponentiation of the coefficient, subtracting one, then multiplying by 100 .

\section{Patient and public involvement}

Data used in this analysis were from public use release files available from the NHANES website. Patients and or public were not involved in the development of research questions, protocols or recruitment. Participants were provided examination test results. Preliminary examination results were provided on completion of the examination and a full report was mailed to participants 12-16 weeks after the examination.

\section{RESULTS}

Table 1 summarises characteristics for the study population $(n=5931)$ and for women of childbearing age $(\mathrm{n}=1580)$, men $(\mathrm{n}=2867)$ and women $(\mathrm{n}=3064)$. Over $80 \%$ of all groups were born in the USA, and the majority of the population was NH white. Roughly one-third of groups completed at least a 4-year college degree. The majority of the groups were non-smokers with $83.44 \%$ (95\% CI $80.87 \%$ to $85.74 \%$ ) among women of childbearing age and $80.9 \%$ (95\% CI $78.4 \%$ to $83.2 \%$ ) among men $\geq 15$ years and $84.9 \%$ (95\% CI $83.0 \%$ to $86.7 \%$ ) among women $\geq 15$ years.

Geometric mean $(95 \% \mathrm{CI}) \quad \mathrm{BPb}$ was $0.89 \mu \mathrm{g} / \mathrm{dL}$ (95\% CI 0.85 to 0.93 ) for the full study population, 1.03 (0.98 to 1.08 ) for men $\geq 15$ years, 0.76 (0.74 to 0.81 ) for women $\geq 15$ years and $0.54 \mu \mathrm{g} / \mathrm{dL}$ (95\% CI 0.51 to 0.57 ) for women of childbearing age (table 2). Among the whole population, $1.30 \%$ (95\% CI $0.86 \%$ to $1.95 \%$ ) had Blood lead level $\geq 5 \mu \mathrm{g} / \mathrm{dL}$. Corresponding proportions for men, women and women of childbearing age were $2.25 \%$ (95\% CI $1.43 \%$ to $3.54 \%$ ), $0.42 \%$ (95\% CI $0.21 \%$ to $0.84 \%$ ) and $0.54 \%$ (95\% CI $0.21 \%$ to $1.44 \%$ ), respectively. Patterns of $\mathrm{BPb}$ levels within demographic categories were similar for all groups. Those born in the USA had lower $\mathrm{BPb}, \mathrm{NH}$ Asians had the highest geometric mean $\mathrm{BPb}$ for all groups with $0.86 \mu \mathrm{g} / \mathrm{dL}(95 \% \mathrm{CI} 0.78$ to 0.95 ) for women of childbearing age, 1.01 (95\% CI 0.94 to 1.09 ) for women $\geq 15$ years, $1.22 \mu \mathrm{g} / \mathrm{dL}$ (95\% CI 1.11 to 1.34) for men $\geq 15$ years and $1.10 \mu \mathrm{g} / \mathrm{dL}$ (95\% CI 1.03 to 1.18) for the entire population. On average, those with less than a high school education had significantly higher $\mathrm{BPb}$. Increasing age was associated with significantly higher $\mathrm{BPb}$ concentrations.

In adjusted regression models, there is a significant difference in $\mathrm{BPb}$ for those not born in the USA compared with those born in the USA among the entire population and all subgroups (table 3 ). Women of childbearing age living in the USA 0-4 years had, on average, a $54.4 \%$ (95\% CI $36.0 \%$ to $75.3 \%$ ) higher BPb compared with those born in the USA. This difference was $46.8 \%$ (22.0\% to $76.7 \%$ ) for women of childbearing age living in the USA 5-9 years, $28.7 \%$ (95\% CI $14.2 \%$ to $45.1 \%$ ) for those living in the USA $10-19$ years and $20.7 \%$ (95\% CI $3.0 \%$ to $41.5 \%$ ) for those living in the USA $\geq 20$ years, all compared with women of childbearing age who were born in the USA. Similar results were seen for women, men and the entire population. Results for model covariates are presented in online supplementary file 1 .

\section{DISCUSSION}

According to our results, there is a statistically significant association of higher $\mathrm{BPb}$ among those not born in the USA compared with US-born persons; the largest difference appears to be among those who came to the USA more recently. This is true for both the full study population as well as the subgroup of women of childbearing age. Higher $\mathrm{BPb}$ was also associated with $\mathrm{NH}$ Asians (compared with $\mathrm{NH}$ whites), having less than a high school education, smoking and males (compared with females).

The observed difference in geometric mean BPb levels by length of time is relatively small; however, small changes can have important public health impacts. Even a small shift in a population mean can result in a substantially larger increase in the number of extreme cases. ${ }^{31}$ Additionally, an increase of $\mathrm{BPb}$ among those with low exposure may have a greater impact than the same increase of $\mathrm{BPb}$ among those with higher levels. ${ }^{32}$

The bulk of the research on $\mathrm{BPb}$ among newcomers has been conducted among children, particularly refugee children. These studies are generally consistent with our results. A cross-sectional study of Greek children found $\mathrm{BPb} \geq 5 \mu \mathrm{g} / \mathrm{dL}$ among $27.7 \%$ of migrants but only $1.2 \%$ 


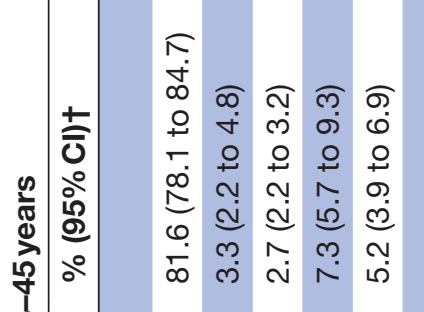
는 बह

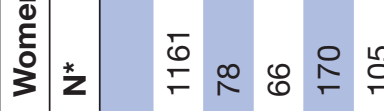
ลุ

$+\quad \stackrel{0}{\infty}$ กิ

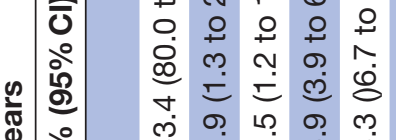

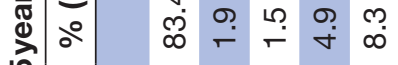
เกิ

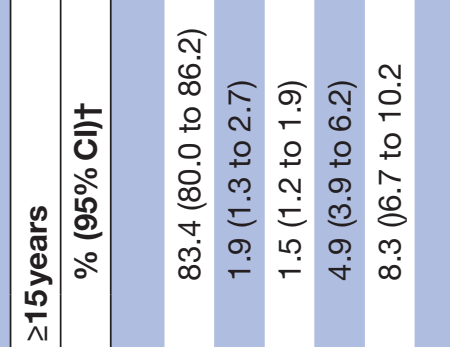
ซै क के 彳) ๓)

$\infty$ เก วิ วิ

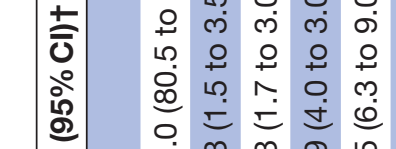
व.

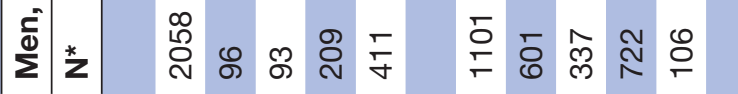<smiles>[18O]=C[Te]</smiles>

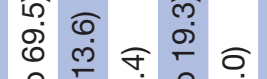
+ 둥ำ

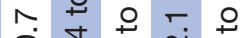
ก) 1
$\infty$

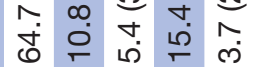

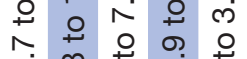
象 ฟิ

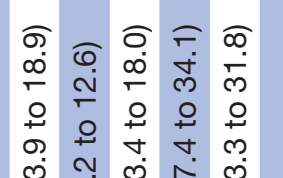
లั) กุ ก ஸे ㅇํ மீं

아.

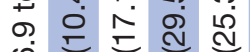

เ 1 व $\infty$ $\infty$ ヘ

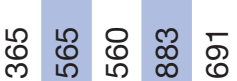

กิ क ลิ

बi $ᄋ$ 웅

O $\leftarrow$ L $N$ N

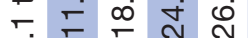

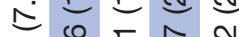

宛
先
ซิ ণิ

$\begin{array}{lll}10 & 10 \\ 0 & 0 \\ 0 & 0 & 0\end{array}$

$\infty$

这 过

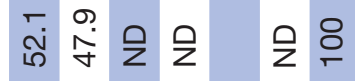

๑ $+\dot{\Gamma}$ ले

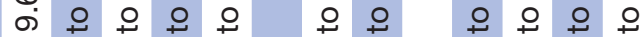

$\circ$.

두 $\sim$ ก

ळ

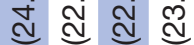

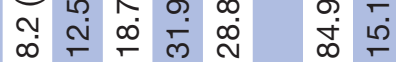

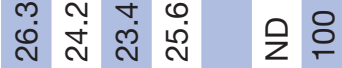

্ָণ

จุด

$\infty \bar{n}$

웅

$\stackrel{\infty}{\stackrel{0}{*}} \stackrel{0}{=}$

○

ळ

孛 స

क ब ल ब

वें

우오 우 우

$100 \%$

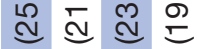

त $\circ$ क क.

$\stackrel{\infty}{\sim} \stackrel{\sim}{\sim} \stackrel{\sim}{\sim} \quad$ 은

\section{ז}

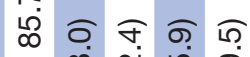

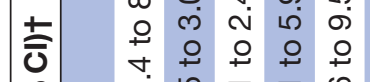

$$
\text { ๙ิ่ }
$$

o $\leftarrow$ 个

+7 유

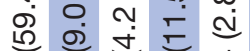

車芒过

N 5 क व

$\stackrel{0}{\circ} \frac{0}{2}$

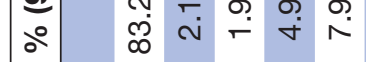

过

ํำ

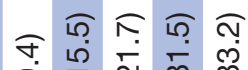

กิ ส

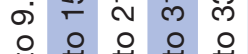

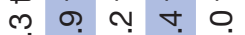

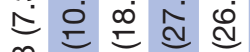

N 0 a d ব

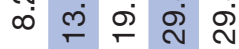

市

우우

r. m

遂

0.

ळ

প

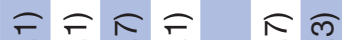

워 $\stackrel{N}{N}$ 守

우우 우

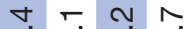

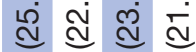

$n-\infty \infty$

+2 웅

人.

กั $\stackrel{\sim}{\sim}$

过 追

$\circ 0$

文 กิ่

\&

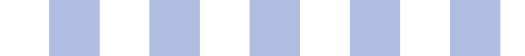

ㄴ.

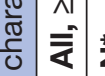

竎官

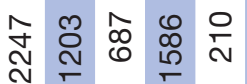

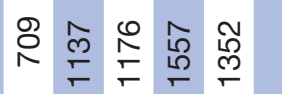

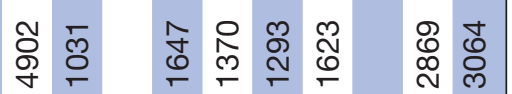


Table 2 Geometric mean (95\% Cl) for blood lead, $\mu \mathrm{g} / \mathrm{dL}$

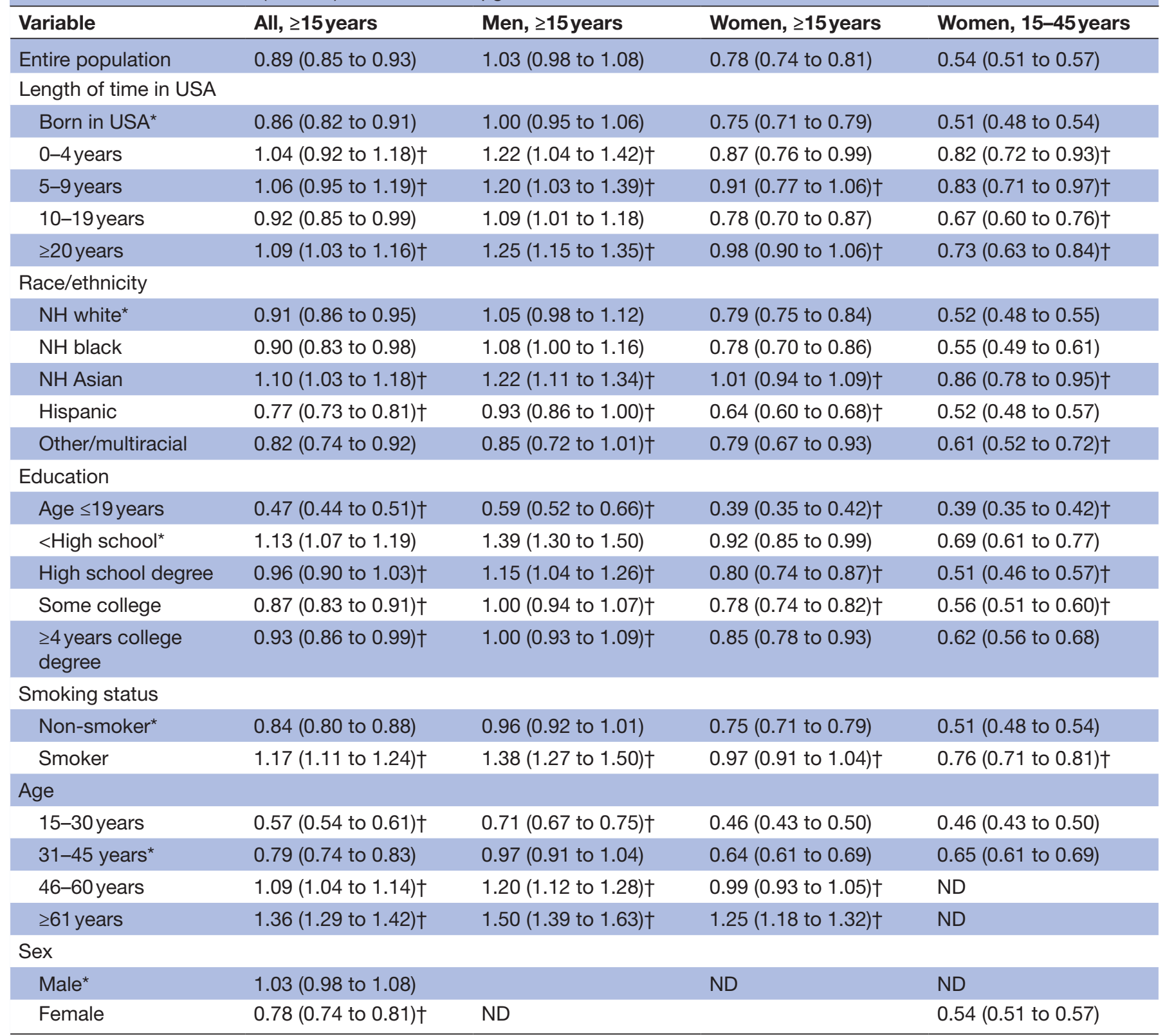

$\mathrm{N}=11740$ (men and women, $\geq 15$ years); $\mathrm{n}=2867$ (men, $\geq 15$ years); $\mathrm{n}=3094$ (women, $\geq 15$ years); $\mathrm{n}=1580$ (women, 15-45 years).

Values are population-weighted per cents.

${ }^{*}$ Referent category.

†Wald test from unadjusted regression model $p<0.05$.

$\mathrm{Cl}$, confidence interval; $\mathrm{ND}$, no data; $\mathrm{NH}$, non-Hispanic.

of natives. ${ }^{18}$ Multiple cross-sectional analyses in the USA have identified that newcomer refugee children settling in Florida, ${ }^{33}$ Kentucky $^{34}$ and New Hampshire ${ }^{14}$ were significantly more likely to have elevated $\mathrm{BPb}$ compared with native children. Additionally, a case-control study of 203 children matched on age, date of test and residential area in New York City found an elevated risk of lead poisoning in foreign-born children relative to US-born children (OR 10.9; 95\% CI 3.3 to 36.5 ). ${ }^{11}$

Our results are also similar to results from prior studies of $\mathrm{BPb}$ in adult women immigrants or newcomers done in other countries. In a study of Taiwanese women, Wu et al report that immigrants from Vietnam, China and Southeast Asia had higher BPb concentrations compared with native born Taiwanese women. ${ }^{20} \mathrm{~A}$ study conducted on 164 newcomer South and East Asian women of reproductive age in Canada found that compared with native born Canadians, newcomer women had higher $\mathrm{BPb}$ than Canadian women, with south Asians having median (95th percentile) $\mathrm{BPb}$ of 1.15 (2.71) $\mu \mathrm{g} / \mathrm{dL}$, and East Asians having $\mathrm{BPb}$ of $1.01(1.81) \mu \mathrm{g} / \mathrm{dL}{ }^{15}$ Asian women in New York City have also been reported to have a disproportionate rate of elevated $\mathrm{BPb}{ }^{35}$ Both the results for newcomer status and ethnicity are consistent with our 
Table $3 \operatorname{Exp}(\beta)(95 \% \mathrm{Cl})$ for the adjusted association of length of time in the USA with $\ln (\mathrm{BPb})$

\begin{tabular}{lllll}
\hline Length of time in USA & All, $\geq \mathbf{1 5 y e a r s}$ & Men, $\geq \mathbf{1 5 y e a r s}$ & Women, $\mathbf{1 5}$ years & Women, 15-45years \\
\hline Born in USA & & & & \\
\hline $0-4$ years & $1.49(1.33$ to 1.66$) \dagger$ & $1.49(1.27$ to 1.75$) \dagger$ & $1.49(1.34$ to 1.66$) \dagger$ & $1.54(1.36$ to 1.75$) \dagger$ \\
5-9years & $1.48(1.31$ to 1.66$) \dagger$ & $1.42(1.89$ to 1.70$) \dagger$ & $1.50(1.28$ to 1.76$) \dagger$ & $1.47(1.22$ to 1.77$) \dagger$ \\
\hline 10-19years & $1.23(1.14$ to 1.66$) \dagger$ & $1.21(1.09$ to 1.33$) \dagger$ & $1.27(1.15$ to 1.39$) \dagger$ & $1.29(1.14$ to 1.45$) \dagger$ \\
$\geq 20$ years & $1.07(1.01$ to 1.14$) \dagger$ & $1.06(0.97$ to 1.17$)$ & $1.08(0.99$ to 1.18$)$ & $1.21(1.03$ to 1.41$) \dagger$ \\
\hline
\end{tabular}

Models adjust for race/ethnicity, education, smoking status, age and sex. $\mathrm{N}=11740$ (men and women, $\geq 15$ years old); $\mathrm{n}=2867$ (men, $\geq$

15 years old); $n=3094$ (women, $\geq 15$ years old); $n=1580$ (women, $15-45$ years old).

Population-weighted values.

${ }^{*}$ Referent category.

†Wald test $\mathrm{p}<0.05$.

$\mathrm{BPb}$, blood lead; $\mathrm{Cl}$, confidence interval.

own results, which found that both of these characteristics were statistically significant and independent predictors of $\mathrm{BPb}$.

In our study, we found that elevated $\mathrm{BPb}$ was higher among newly arrived adults and adolescents to the USA, and that concentrations were lower with an increased amount of time spend in the USA. This was similar to result found by $\mathrm{Wu}$ et al, who conducted a study on immigrant women from China and South East Asia and found that $\mathrm{BPb}$ concentrations decrease significantly with time in Taiwan; with immigrants living in country $\leq 5$ years having $\mathrm{BPb}$ of $2.6 \mu \mathrm{g} / \mathrm{dL}$ (95\% CI 2.45 to 2.89 ) and immigrants living in the country $>5$ years having $\mathrm{BPb}$ of $2.40 \mu \mathrm{g} / \mathrm{dL}$ (95\% CI 2.21 to 2.59 ) compared with non-immigrant women. ${ }^{20}$ This suggests that there is a need of more detailed investigation into the toxic exposures and health status of 'newcomers' to any population, examine the related contexts and intervene to address this disparity.

One limitation of this analysis is that we do not have the ability to determine the source of lead exposure in this population. The 2013-2016 NHANES data that was used for this study is cross-sectional and thus lacks the ability to determine the temporal sequence of exposure and outcome; to determine a directional relationship between exposure and outcome a longitudinal study is required. Another limitation of this study design is that participants had blood drawn only once; thus, we could not capture change in BPb over time, as mobilisation of lead from bones especially during turnover and osteoporosis influences the concentration of lead in blood for years. ${ }^{36}$ Additionally, our study used $\mathrm{BPb}$, which generally reflects current lead exposure, not necessarily cumulative lead exposure. $^{23}$

In a newcomer population, the source of the lead exposure reflected in $\mathrm{BPb}$ may have originated from either the origin or destination country or both. Lead exposure from the country of origin may occur due to continued use of lead in many countries, ${ }^{3}$ the situation in which the newcomer lived or other socioecological factors that are associated with $\mathrm{BPb}$ levels. Once in the destination country, it is possible that continued use of lead-containing products may contribute to lead exposure. ${ }^{16}{ }^{37}$ Newcomers may also be likely to live in areas with a higher risk of environmental lead exposure such as areas with elevated industrial activity, proximity to busy roads or increased proportion of older homes that have lead paint. ${ }^{38}$ Meanwhile, studies have shown that immigrants are at higher risk of elevated stress as represented from increased allostatic load ${ }^{39}$; this is of concern as it has been demonstrated that health impacts associated with lead exposure may be exacerbated among those with a greater allostatic load. ${ }^{40}$ Thus, newcomers may not only have a higher risk of being exposed to lead within the destination country compared with native born individuals, but they may also be more susceptible to lead toxicity.

This study also has several strengths. First, the sample was drawn from a large, representative sample of non-institutionalised civilian population of the USA and incorporated non-response into survey weights, which minimises the potential for selection bias to affect our results. Second, the study population was diverse with regard to age, sex, race/ethnicity and education. Finally, we were one of only a few studies to date which have examined the association between length of time since arrival in the USA and $\mathrm{BPb}$. We also present similar data for all persons $\geq 15$ years or older; to the best of our knowledge, no prior publications have focused specifically on women of childbearing age.

The results from the present study, taken together with the existing literature, suggest that newcomer or immigrant populations may be at risk for elevated lead exposure and thus face greater health disparities. The US CDC has existing recommendations that $\mathrm{BPb}$ testing should be conducted on 6 months to 6 years children, 3 to 6 months after resettlement in the USA ${ }^{41}$; extending such screening to at risk population such as women of childbearing age and newcomers to the USA, particularly those from Asian countries, may be warranted.

\section{CONCLUSIONS}

Our study demonstrated that there was a significant association between self-reported length of time in the USA and $\mathrm{BPb}$, with $\mathrm{BPb}$ levels highest for those reporting living in the USA for $0-4$ years or 5-9 years. These results, along with prior evidence, suggest newcomer populations, 
especially newcomer women of childbearing age, are a population of concern for elevated $\mathrm{BPb}$.

Contributors CJH and EMW conceived and designed the experiments. CJH performed data analyses as well as wrote the initial manuscript. LA and EMW offered support for the manuscript by reviewing and editing all drafts and providing suggestions for improvements to analyses and interpretations. All authors reviewed and contributed to various sections to improve and approve the final manuscript.

Funding The authors have not declared a specific grant for this research from any funding agency in the public, commercial or not-for-profit sectors.

Competing interests None declared.

Patient consent for publication Not required.

Ethics approval National Center for Health Statistics (NCHS) Research Ethics Review Board (ERB) Approval Protocol \#2011-17.

Provenance and peer review Not commissioned; externally peer reviewed.

Data sharing statement Data used in this study are available for download at the National Health and Nutrition Examination Survey websites, https://wwwn.cdc.gov/ nchs/nhanes/Default.aspxandhttps://www.cdc.gov/nchs/data-linkage/mortality.htm; computer code will be made available on request.

Open access This is an open access article distributed in accordance with the Creative Commons Attribution Non Commercial (CC BY-NC 4.0) license, which permits others to distribute, remix, adapt, build upon this work non-commercially, and license their derivative works on different terms, provided the original work is properly cited, appropriate credit is given, any changes made indicated, and the use is non-commercial. See: http://creativecommons.org/licenses/by-nc/4.0/.

\section{REFERENCES}

1. Nriagu JO. Occupational exposure to lead in ancient times. Sci Total Environ 1983;31:105-16.

2. Flegal AR, Smith DR. Current needs for increased accuracy and precision in measurements of low levels of lead in blood. Environ Res 1992;58:125-33.

3. Tong S, von Schirnding YE, Prapamontol T. Environmental lead exposure: a public health problem of global dimensions. Bull World Health Organ 2000;78:1068-77.

4. Tsoi MF, Cheung CL, Cheung TT, et al. Continual Decrease in Blood Lead Level in Americans: United States National Health Nutrition and Examination Survey 1999-2014. Am J Med 2016;129:1213-8.

5. Matović V, Buha A, Đukić-Ćosić D, et al. Insight into the oxidative stress induced by lead and/or cadmium in blood, liver and kidneys. Food Chem Toxicol 2015;78:130-40.

6. Council on Environmental Health. Prevention of Childhood Lead Toxicity. Pediatrics 2016;138.

7. Centers for Disease Control and Prevention (CDC). Adult Blood Lead Epidemiology and Surveillance (ABLES). 2017 https://www.cdc.gov/ niosh/topics/ables/description.html (Accessed 15 Mar 2018).

8. Schwartz J. Low-level lead exposure and children's IQ: a metaanalysis and search for a threshold. Environ Res 1994;65:42-55.

9. Prins E, Monnat $S$. Examining associations between self-rated health and proficiency in literacy and numeracy among immigrants and u.S.-Born adults: Evidence from the Program for the International Assessment of Adult Competencies (PIAAC). PLoS One 2015;10:e0130257

10. Singh GK, Siahpush M. Ethnic-immigrant differentials in health behaviors, morbidity, and cause-specific mortality in the United States: an analysis of two national data bases. Hum Biol 2002;74:83-109.

11. Tehranifar $\mathrm{P}$, Leighton $\mathrm{J}$, Auchincloss $\mathrm{AH}$, et al. Immigration and risk of childhood lead poisoning: findings from a case control study of New York City children. Am J Public Health 2008;98:92-7.

12. Eisenberg KW, van Wijngaarden E, Fisher SG, et al. Blood lead levels of refugee children resettled in Massachusetts, 2000 to 2007. Am J Public Health 2011:101:48-54.

13. Schmidt CW. Unsafe harbor? Elevated blood lead levels in refugee children. Environ Health Perspect 2013;121:A190-5.

14. Raymond JS, Kennedy C, Brown MJ. Blood lead level analysis among refugee children resettled in New Hampshire and Rhode Island. Public Health Nurs 2013;30:70-9.

15. Dix-Cooper L, Kosatsky T. Blood mercury, lead and cadmium levels and determinants of exposure among newcomer South and East Asian women of reproductive age living in Vancouver, Canada. Sci Total Environ 2018;619-620:1409-19.
16. Parnia A, Chakravartty D, Wiseman CLS, et al. Environmental factors associated with blood lead among newcomer women from South and East Asia in the Greater Toronto Area. Sci Total Environ 2018;624:558-66.

17. Chen SX, Wiseman CL, Chakravartty D, et al. Metal Concentrations in Newcomer Women and Environmental Exposures: A Scoping Review. Int J Environ Res Public Health 2017;14:277.

18. Tanaka M, Petsios K, Dikalioti S, et al. Lead Exposure and Associated Risk Factors among New Migrant Children Arriving in Greece. Int J Environ Res Public Health 2018;15:1057.

19. Wu WT, Liou SH, Lin KJ, et al. Changing blood lead levels and DNA damage (comet assay) among immigrant women in Taiwan. Sci Total Environ 2009;407:5931-6.

20. Wu WT, Wu CC, Lin YJ, et al. Changing blood lead levels and oxidative stress with duration of residence among Taiwan immigrants. J Immigr Minor Health 2013;15:1048-56.

21. Keating D, Fischer-Baum R. How U.S. immigration has changed: Washington Post, 2018. https://www.washingtonpost.com/graphics/ 2018/national/immigration-waves/?noredirect=on\&utm_term=. 5301129f82fb. (Accessed 5 Aug 2018).

22. Commodore-Mensah $\mathrm{Y}$, Ukonu N, Obisesan O, et al. Length of residence in the united states is associated with a higher prevalence of cardiometabolic risk factors in immigrants: A contemporary analysis of the national health interview survey. J Am Heart Assoc 2016;5.

23. Hu H, Shih R, Rothenberg $\mathrm{S}$, et al. The epidemiology of lead toxicity in adults: measuring dose and consideration of other methodologic issues. Environ Health Perspect 2007;115:455-62.

24. Gulson BL, Mizon KJ, Korsch MJ, et al. Mobilization of lead from human bone tissue during pregnancy and lactation-a summary of long-term research. Sci Total Environ 2003;303:79-104.

25. Gulson BL, Mahaffey KR, Mizon KJ, et al. Contribution of tissue lead to blood lead in adult female subjects based on stable lead isotope methods. J Lab Clin Med 1995;125:703-12.

26. Lagerkvist BJ, Ekesrydh S, Englyst $\mathrm{V}$, et al. Increased blood lead and decreased calcium levels during pregnancy: a prospective study of Swedish women living near a smelter. Am J Public Health 1996;86:1247-52.

27. Chuang HY, Schwartz J, Gonzales-Cossio T, et al. Interrelations of lead levels in bone, venous blood, and umbilical cord blood with exogenous lead exposure through maternal plasma lead in peripartum women. Environ Health Perspect 2001;109:527-32.

28. Alba A, Carleton L, Dinkel L, et al. Increased lead levels in pregnancy among immigrant women. J Midwifery Womens Health 2012;57:509-14.

29. , Wheeler W, Brown MJ; Centers for Disease Control and Prevention (CDC). Blood lead levels in children aged 1-5 years - United States, 1999-2010. MMWR Morb Mortal Wkly Rep 2013;62:245-8.

30. Lee MG, Chun OK, Song WO. Determinants of the blood lead level of US women of reproductive age. J Am Coll Nutr 2005;24:1-9.

31. Braun JM. Early-life exposure to EDCs: role in childhood obesity and neurodevelopment. Nat Rev Endocrinol 2017;13:161-73.

32. Lanphear BP, Hornung R, Khoury J, et al. Low-level environmental lead exposure and children's intellectual function: an international pooled analysis. Environ Health Perspect 2005;113:894-9.

33. Trepka MJ, Pekovic V, Santana JC, et al. Risk factors for lead poisoning among Cuban refugee children. Public Health Rep 2005;120:179-85.

34. Kotey S, Carrico R, Wiemken TL, et al. Elevated Blood Lead Levels by Length of Time From Resettlement to Health Screening in Kentucky Refugee Children. Am J Public Health 2018;108:270-6.

35. Hore P, Ahmed MS, Sedlar S, et al. Blood lead levels and potential risk factors for lead exposures among South Asians in New York City. $J$ Immigr Minor Health 2017;19:1322-9.

36. Menke A, Muntner P, Batuman V, et al. Blood lead below 0.48 $\mathrm{micromol} / \mathrm{L}$ (10 microg/dL) and mortality among US adults. Circulation 2006;114:1388-94.

37. Kaplowitz SA, Perlstadt H, Dziura JD, et al. Behavioral and Environmental Explanations of Elevated Blood Lead Levels in Immigrant Children and Children of Immigrants. J Immigr Minor Health 2016;18:979-86.

38. Abdulrahman DM, Horton SB. Explaining lead poisoning among refugee children: The role of the resettlement process. Hum Organ 2018;77:90-101.

39. McClure HH, Josh Snodgrass J, Martinez CR, et al. Stress, place, and allostatic load among mexican immigrant farmworkers in Oregon. J Immigr Minor Health 2015;17:1518-25.

40. Zota AR, Shenassa ED, Morello-Frosch R. Allostatic load amplifies the effect of blood lead levels on elevated blood pressure among middle-aged U.S. adults: a cross-sectional study. Environ Health 2013;12:64. 
41. Centers for Disease Control and Prevention (CDC). CDC

Recommendations for lead poisoning prevention in newly arrived refugee children. 2013 https://www.cdc.gov/nceh/lead/publications/ refugeetoolkit/pdfs/cdcrecommendations.pdf (Accessed 7 Aug 2018). 